\title{
Type 1 diabetes islet associated antibodies in subjects infected by echovirus 16
}

\author{
E. Cabrera-Rode1 ${ }^{1}$ L. Sarmiento ${ }^{2}$, C. Tiberti ${ }^{3}$, G. Molina ${ }^{1}$, J. Barrios ${ }^{2}$, D. Hernández ${ }^{2}$, O. Díaz-Horta ${ }^{1}$, \\ U. Di Mario ${ }^{3}$ \\ ${ }^{1}$ Department of Immunology of Diabetes, National Institute of Endocrinology, Zapata and D, Havana, Cuba \\ ${ }^{2}$ Institute of Tropical Medicine "Pedro Kouri", Havana, Cuba \\ ${ }^{3}$ University of Rome "La Sapienza”, Clinica Medica 2, Rome, Italy
}

\section{Abstract}

Aims/hypothesis. To determine whether the emergent infection by echovirus 16 that occurred in Cuba during the year 2000 was related to the presence of Type 1 diabetes associated autoantibodies.

Methods. The presence of ICA, IAA, GADA, IA2 antibodies and neutralizing antibodies (NtAb) to echovirus 16 were determined in sera from 38 infected children and adolescents and 80 control subjects, matched in sex, age, local residence and time of sample collection.

Results. The occurrence of a large-scale echovirus 16 epidemic was associated with the appearance of humoral autoimmune markers of Type 1 diabetes, especially for ICA, IAA and GADA. In the convalescent stage, ICA, IAA and GADA seroconversion was shown in $92.1 \%, 44.7 \%$ and $28.9 \%$ of echovirus 16 infected subjects. None of the 80 uninfected subjects had ICA or IAA, while one was GADA positive. ICA,
IAA and GADA frequency was higher in the convalescent than in the acute stage $(p<0.0005)$. A strong positive correlation was found between the NtAb to echovirus 16 and ICA titres in both acute and convalescent stage $(\mathrm{r}=0.91 ; p<0.0001, \mathrm{r}=0.55 ; p=0.0003$ respectively).

Conclusion/interpretation. This work provides evidence of an association between echovirus 16 infection and the presence of Type 1 diabetes related antibodies (ICA, IAA and GADA). Our data show that the echovirus 16 infection might be capable of inducing a process of autoimmune beta-cell damage and support the hypothesis that enterovirus infections are important risk factors for the development of Type 1 diabetes. [Diabetologia (2003) 46:1348-1353]

Keywords Islet cell antibodies, insulin autoantibodies, glutamic acid decarboxylase antibodies, tyrosine phosphatase antibodies, virus, enterovirus, echovirus, neutralizing antibodies, Type 1 diabetes.
Received: 10 December 2002 / Revised: 23 April 2003

Published online: 29 July 2003

C) Springer-Verlag 2003

Corresponding author: E. Cabrera-Rode, Department of Immunology of Diabetes, National Institute of Endocrinology, Zapata and D, Havana 10 400, Cuba

E-mail: diabetes@infomed.sld.cu

Abbreviations: EV, echovirus; ICA, islet cell antibodies; IAA, insulin autoantibodies; GADA, glutamic acid decarboxylase antibodies; IA2A, tyrosine phosphatase antibodies; NtAb, neutralizing antibodies; TMA, thyroid microsomal antibodies; PGA, parietal gastric cells antibodies; JDF, juvenile diabetes foundation; CVB4, coxsackie virus B4; CVB5, coxsackie virus B5.
Type 1 diabetes mellitus is an autoimmune disease in which insulin deficit is the result of pancreatic betacell destruction due to a specific immunological response against these cells as a consequence of an interaction between the genetic susceptibility (polygenic) and unknown environmental factors $[1,2,3,4,5,6]$.

Among the environmental factors that could play an important role in triggering autoimmunity are numerous viruses of different genera $[1,3,4,6,7]$, such as mumps, rubella, cytomegalovirus, rotavirus and enteroviruses $[1,3,6,8,9,10]$.

Enteroviruses, specifically, coxsackie group B virus $[1,3,6,8,9,10,11]$, are the most important group of viruses that have been found to have a strong relation to Type 1 diabetes. 
Islet cell antibodies (ICA), insulin autoantibodies (IAA), antibodies to the $M_{r} 65000$ isoform of glutamic acid decarboxylase (GADA) and antibodies to the intracellular portion of the protein tyrosine phosphatase-related IA2 molecule (IA2A), precede the development of clinical diabetes and are therefore commonly used as markers of pre-clinical disease $[12,13]$. The presence of several antibodies indicates a higher risk of developing such disease as opposed to positivity for only one autoantibody $[12,13]$.

ICA has been detected in non-diabetic subjects infected with different viruses (mumps, rubella and coxsackie B4) [1, 14]. An eventual association between enterovirus infections and seroconversion to ICA has been described in a few cases $[6,9,10,11,15]$. The presence of ICA is one of the best markers of beta cell-damaging autoimmunity, and ICA seroconversion can be considered a sign of the induction of the process.

Our group has reported the association between ICA presence and the meningitis epidemic caused by echovirus 4 [11, 16, 17, 18], and we have found metabolic abnormalities during an oral glucose tolerance test (OGTT) in children infected by this virus $[14,17$, 18]. It has been shown that beta cells from mice infected with echovirus 4 (isolated strains from children of the previously mentioned epidemic) produced less insulin and had reduced synthesis of total proteins [14]. Such changes were related to alterations in their blood glucose concentrations.

Furthermore, our group found higher frequencies of neutralizing antibodies against echovirus 4 in newlydiagnosed Type 1 diabetic patients compared to a control group (22.0\% vs $1.8 \%$ ) [19]. It is possible that exposure to specific viruses which stimulate clones of $\mathrm{T}$ cells that might cross-react with specific extra-thymic antigens of beta cells (molecular mimicry) could induce an immunological response against those cells. For example, it is known that $\mathrm{P} 2-\mathrm{C}$ is one of the proteins of coxsackie B4 (CVB4) and it shares homology sequences with GAD65 protein, present in beta cells of pancreatic islets $[1,11,20]$. Other homologies have been found among viral proteins (in cytomegalovirus, rubella, retrovirus and rotavirus) and beta-cell autoantigens (38KD and 52KD proteins, insulin and IA2) [1, 7].

From April to September 2000, an epidemic of aseptic meningitis caused by echovirus 16 spread throughout Cuba [21]. This was the first evidence in the world of a large-scale epidemic by echovirus 16 (EV16).

Taking into account the aforementioned facts, we determined whether there is a relationship between the infection of echovirus 16 and the presence of antibodies associated with Type 1 diabetes (ICA, IAA, GADA and IA2A).

\section{Subjects and methods}

Epidemic data. From April to September 2000, an epidemic of aseptic meningitis spread throughout Cuba, with 16943 reported cases. Most of the patients were children under 15 years old. The highest incidence corresponded to infants of less than 1 year of age, followed by the 1- to-9-year-old group, and none of the infant cases were neonates. Vomiting $(91.5 \%)$, headache $(88.1 \%)$, and fever $(72.8 \%)$ were the predominant clinical manifestations; few patients had diarrhoea $(11.8 \%)$ or skin rash $(6.8 \%)$ [21]. None of the infected children had altered blood fasting glucose concentrations.

To establish the diagnosis of enterovirus, 54 cerebrospinal fluid (CSF), 76 faecal samples and, 31 paired sera from the acute and convalescent phases were obtained from 98 children with symptoms suggestive of aseptic meningitis. CSF and faecal samples were collected only once per child, at onset of symptoms. The children were admitted to different hospitals in 11 of Cuban's 14 provinces. Specimens were collected from May 5 to August 11, 2000 and transported frozen to the Enterovirus laboratory, "Pedro Kouri" Tropical Medicine Institute [21].

We used conventional methods for diagnosis of enterovirus and an in-house-developed reverse transcriptase-nested polymerase chain reaction (RT-N-PCR) assay of CSF specimens [21]. For the enterovirus genome detection, RNA was extracted from $250 \mu$ of CSF using TRIzol (Life Technologies, Gibco BRL; Grand Island, N.Y., USA), according to the manufacturer's instructions. RNA amplification was carried out by a method previously described [22], except that two amplification rounds were used. Oligonucleotides used for RT, first PCR and second-round PCR were derived from within the 5'noncoding region $\left(5^{\prime} \mathrm{NCR}\right)$, a highly conserved zone in enterovirus serotypes that allows a near-universal amplification of the enteroviruses $[23,24]$. The sensitivity $(0.01$ tissue culture infective dose, $\mathrm{TCID}_{50}$ ) and specificity of our enterovirus-RNA detection assay [21] allowed us to detect specific enterovirus RNA sequences in $46.3 \%$ (25 of 54) of the CSF specimens.

For enterovirus isolation, $200 \mu \mathrm{l}$ of CSF and faecal specimens were inoculated in duplicate into tubes covered with monolayers of fibroblastic diploid embrionic human cells (PhuE-1) and monkey kidney cells (Vero).

From the 76 faecal specimens inoculated, 45 (59.2\%) induced cytopathic effect (CPE). This CPE was only evident in the PhuE-1 cell monolayers; Vero cells remained invariable. Viral isolation was possible from all the tubes showing CPE.

All strains from the epidemic were identified as echovirus 16 by a neutralization test using the Lim-Benyesh-Melnick (LBM) antisera pools. To corroborate the infecting serotype, presence of a four-fold or greater increase of the type-specific virus-neutralizing antibody titres between sera specimens from the acute and the convalescent phase was determined. It was found that $54.8 \%$ of the patients' sera showed a rise of neutralizing antibody titre against the isolated strains. The geometric mean titre of the first and second sera was 1:3.4; and 1:22.4, respectively [21].

All Cuban aseptic meningitis epidemic cases from the year 2000 were associated with echovirus 16 . None were caused by other agents.

Subjects. We obtained 38 sera samples from children and adolescents in the acute and convalescent stage (age ranged from 11 to 156 months, $86 \pm 49$; mean $\pm \mathrm{SD}$ ) randomly selected from a large-scale echovirus 16 meningitis epidemic throughout the country [21]. The acute serum was taken five/five to six (median/range) days after the beginning of the infection (at onset of the clinical symptoms), and the convalescent serum when the patients recovered completely $30 / 29$ to 35 (median/range) days after the beginning of the infection. 
We determined the presence of neutralizing antibodies against echoviruses in these sera (EV4, EV6, EV9, EV11, EV16 and EV30). Sera samples from 80 healthy children and adolescents (age ranged from 11 to 153 months, 88ะ47; means $\pm \mathrm{SD}$ ), who were serologically verified as negative for neutralizing antibodies to echovirus 16, were also used. These sera were paired for sex, age, location of residence and time of sample collection in relation to children and adolescents who were infected by echovirus 16 .

All subjects, or their parents, gave their informed consent to be studied, and the local Ethical Committee approved the protocol.

All sera were submitted for determination of the presence of islet cell antibodies (ICA), insulin autoantibodies (IAA), glutamic acid decarboxylase antibodies (GADA) and tyrosine phosphatase antibodies (IA2A). Measurement of thyroid microsomal antibodies (TMA) and parietal gastric cells antibodies (PGA) were only carried out in subjects infected in order to show the specific pancreatotoxic activity of this infection.

Islet cell antibodies (ICA). The presence of ICA was determined in all sera by the indirect immunofluorescence technique with prolonged incubation $(18 \mathrm{~h})$ using frozen human pancreas of $\mathrm{O}$ blood group in the presence of protease inhibitor (Inhprot I, $400 \mathrm{UI} / \mathrm{ml}$, University of Havana, Cuba) as described $[19,25,26]$. All subjects with ICA titres higher or equal to $10 \mathrm{JDF}$ units were considered positive. Our laboratory (lab 274, Havana, Cuba) obtained $75 \%$ sensitivity and $75 \%$ specificity in the $8^{\text {th }}$ ICA Proficiency Test held in 1993 organized by Noel MacLaren, University of Florida, USA.

Insulin autoantibodies (IAA). Insulin autoantibodies were detected using a competitive fluid-phase radioimmunoassay [27]. In the Fourth International Diabetes Workshop IAA proficiency test program held in 1994, University of Florida, our laboratory (lab 232, Havana, Cuba) obtained $100 \%$ specificity and $43 \%$ sensitivity. The cut-off for this assay is $40 \mathrm{nU} / \mathrm{ml}$ and was established as the $99^{\text {th }}$ centile of the IAA concentrations detected in 100 healthy control subjects without history of diabetes.

Glutamic acid decarboxylase antibodies (GADA). Autoantibodies against GAD65 were detected by a quantitative radioimmunoprecipitation assay [28], using in vitro synthesized human recombinant ${ }^{35} \mathrm{~S}$-methionine-labelled GAD65 and $50 \%$ protein A-sepharose to separate free from antibody-bound labelled GAD65. Results were expressed as an index (index = sample cpm-negative standard control cpm / positive standard control cpm-negative standard control cpm). A GADA index 0.035 was used as the limit of positivity. In the First International Diabetes Workshop GAD Proficiency Program, our laboratory (Rome, Italy) obtained $100 \%$ sensitivity and specificity. Subsequently, we participated with this assay in the Combinatorial islet autoantibody workshop [29] and in DASP 2001 and DASP 2002 IDS/CDC autoantibody programs. In DASP 2002 our laboratory (lab 155, Rome, Italy) obtained $97 \%$ specificity and $88 \%$ sensitivity.
Tyrosine phosphatase antibodies (IA2A). Tyrosine phosphatase antibodies determinations were made by a quantitative radioimmunoprecipitation assay in fluid phase [28], using in vitro synthesized human recombinant ${ }^{35} \mathrm{~S}$-methionine-labelled ICA 512 bdc/IA2. An in vitro transcription and translation system was used in rabbit reticulocytes for the labelling. Values of IA2A higher than 0.072 were considered as positive. We participated with this assay in the Combinatorial islet autoantibody workshop [29] and in DASP 2001 and DASP 2002 IDS/CDC autoantibody programs. In DASP 2002 our laboratory (lab 155, Rome, Italy) obtained $100 \%$ specificity and $60 \%$ sensitivity.

Thyroid microsomal antibodies (TMA) and parietal gastric cells antibodies (PGA). The measurement of TMA and PGA were done by the same indirect immunofluorescence technique, using human thyroid frozen sections obtained in a thyroidectomy of $\mathrm{O}$ blood group, and the stomach of Wistar rats respectively [25]. We considered subjects positive for TMA and PGA as those presenting with fluorescence on the basis of $1: 4$ and 1:10 dilution of sera respectively.

Neutralizing antibodies (NtAb). The titre of neutralizing antibodies was determined by the method recommended by WHO [30] with two modifications, namely, the use of culture tubes covered with monolayers of fibroblastic diploid embryonic human cell (PhuE-1) and two-fold serial dilutions of sera beginning with 1:10. At each dilution, $50 \mu \mathrm{l}$ of diluted serum was mixed with $50 \mu \mathrm{l}$ of medium (Eagle MEM) containing 100 TCID50 (32-320) of EV4, EV6, EV9, EV11, EV16 or EV30. The virus-serum mixture was incubated for $4 \mathrm{~h}$ at $37 \mathrm{C}$. The mixture was then inoculated onto PhuE-1 cell monolayers and incubated as before for 5 days. Each serum was tested in triplicate and each test batch was accompanied by the following controls: cell control, serum toxicity control, virus dose and titration controls using an in-house reference serum validated against the international standard.

Statistical analysis. The statistical significance of the differences between groups in relation to ICA, IAA, GADA, IA2A and $\mathrm{NtAb}$ frequency was analyzed by the Chi-square or Fisher's exact test. Spearman's test of rank correlation was used to compare the degree of correlation between the antibodies titres against echovirus 16 and ICA. A $p$ value of less than 0.05 was considered to be statistically significant.

\section{Results}

The analysis of neutralizing antibodies (NtAb) to echoviruses $4,6,9,11,16$ and 30 during the meningitis epidemic showed a high frequency of $\mathrm{NtAb}$ to EV16 at the convalescent stage compared to the acute stage of the infection $(p=0.0006)$ (Table 1$)$.

Table 1. Frequency of neutralizing antibodies against different echovirus serotypes in children and adolescents affected by viral meningitis infection

\begin{tabular}{lllllrr}
\hline Stage & $\begin{array}{l}\text { EV4 } \\
+(\%)\end{array}$ & $\begin{array}{l}\text { EV6 } \\
+(\%)\end{array}$ & $\begin{array}{l}\text { EV9 } \\
+(\%)\end{array}$ & $\begin{array}{l}\text { EV11 } \\
+(\%)\end{array}$ & $\begin{array}{l}\text { EV16 } \\
+(\%)\end{array}$ & $\begin{array}{r}\text { EV30 } \\
+(\%)\end{array}$ \\
\hline 1 & $3(7.9)$ & $14(36.8)$ & $23(60.5)$ & $21(55.2)$ & $6(15.8)$ & $9(23.7)$ \\
2 & $4(10.5)$ & $18(47.3)$ & $26(68.4)$ & $22(57.8)$ & $21(55.2)^{\mathrm{a}}$ & $10(26.3)$ \\
\hline
\end{tabular}

Stage 1: Acute infection of meningitis during the epidemic by echovirus 16

Stage 2: Convalescence of meningitis infection by echovirus 16

a $p=0.0006$ vs stage 1 
Table 2. Frequency of islet cell antibodies (ICA),insulin autoantibodies (IAA), glutamic acid decarboxylase antibodies (GADA) and tyrosine phosphatase antibodies (IA2A) in children and adolescents affected by echovirus 16 infection

\begin{tabular}{llll}
\hline Autoantibodies & $\begin{array}{l}\text { Stage 1 } \\
+/ n(\%)\end{array}$ & $\begin{array}{l}\text { Stage 2 } \\
+/ n(\%)\end{array}$ & $\begin{array}{l}\text { Control } \\
+/ n(\%)\end{array}$ \\
\hline ICA & $5 / 38(13.1)$ & $35 / 38(92.1)^{\mathrm{a}}$ & $0 / 80(0.0)$ \\
IAA & $0 / 38(0.0)$ & $17 / 38(44.7)^{\mathrm{a}}$ & $0 / 80(0.0)$ \\
AGAD & $0 / 38(0.0)$ & $11 / 38(28.9)^{\mathrm{bc}}$ & $1 / 80(1.2)$ \\
AIA2 & $0 / 38(0.0)$ & $0 / 38(0.0)$ & $0 / 80(0.0)$ \\
\hline
\end{tabular}

Stage 1: Acute infection of meningitis during the epidemic by echovirus 16

Stage 2: Convalescence of meningitis infection by echovirus 16

Control: Negative for neutralizing antibodies to echovirus 16 ${ }^{\mathrm{a}} p<0.0001$ vs stage 1 and control, ${ }^{\mathrm{b}} p=0.0004$ vs stage 1 , ${ }^{\mathrm{c}} p<0.0001$ vs control

Table 3. ICA titres in children and adolescents affected by echovirus 16 according to the stage of infection

\begin{tabular}{lcl}
\hline Stage & $\begin{array}{l}\text { ICA }<40 \text { UJDF } \\
+(\%)\end{array}$ & $\begin{array}{l}\text { ICA } \geq 40 \text { UJDF } \\
+(\%)\end{array}$ \\
\hline $1(n=5)$ & $\begin{array}{l}5(100.0) \\
2(n=35)\end{array}$ & $\begin{array}{l}0(0.0) \\
9(25.7)\end{array}$ \\
\hline
\end{tabular}

Stage 1: Acute infection of meningitis during the epidemic by echovirus 16

Stage 2: Convalescence of meningitis infection by echovirus 16

$n$ : Total of ICA-positive subjects

ICA, IAA and GADA presence was higher during the convalescent stage of infection than in the acute stage and the control group $(p<0.001)$. In contrast, we did not find positivity to IA2 in any of the stages (Table 2).

The titres of NtAb antibodies to EV16 were correlated with the ICA titres, both in the acute and convalescent stages $(\mathrm{r}=0.91 ; p<0.0001, \mathrm{r}=0.55, p=0.0003$ respectively) of echovirus 16 infection (Fig. 1).

An increase in the frequency of high ICA titres was shown in the convalescent stage although no statistical differences were found compared to those of the acute stage of infection (Table 3).

We found the highest frequencies of GADA in high titre ICA positive sera during the convalescent stage of EV6 infection. GADA were positive in $19.2 \%$ $(5 / 26)$ of subjects with ICA less than $40 \mathrm{JDFU}$ and in $66.6 \%(6 / 9)$ of subjects with ICA greater than or equal to $40 \mathrm{JDFU}(p=0.0146)$. The presence of IAA was also higher in subjects with ICA greater than or equal to $40 \mathrm{JDFU}(77.7 \%, 7 / 9)$ in contrast to subjects with ICA less than 40 JDFU $(30.7 \%, 8 / 26 ; p=0.0216)$. In addition, IAA frequency was higher in GADA positive subjects $(81.8 \%, 9 / 11)$ compared to GADA negative subjects $(29.6 \%, 8 / 27 ; p=0.0049)$.
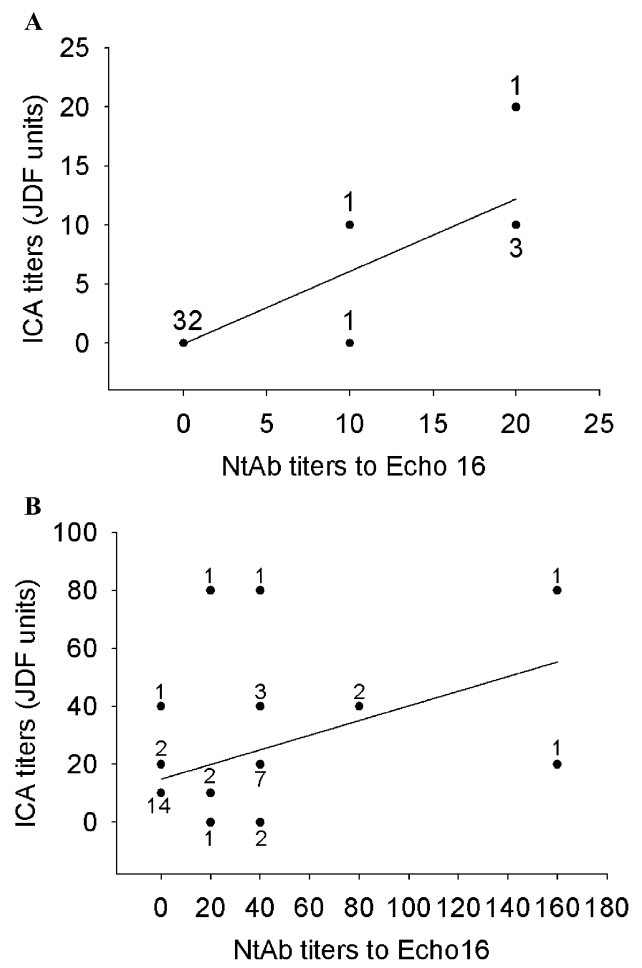

Fig. 1A, B. A Correlation of ICA and NtAb to echovirus 16 titres during the acute stage of meningitis infection $(\mathrm{r}=0.91$, $p<0.0001)$ and $\mathbf{B}$ in the convalescence stage of meningitis infection by echovirus $16(\mathrm{r}=0.55 ; p=0.0003)$

None of the 38 matched sera obtained during the echovirus 16 epidemic were positive for thyroid microsomal antibodies (TMA) or parietal gastric cells antibodies (PGA).

\section{Discussion}

Different prospective studies suggest that enterovirus infection might initiate and/or accelerate the process of beta-cell destruction, years before the clinical manifestation of Type 1 diabetes [8, 9, 10, 15, 31, 32]. In addition, it is possible that such viruses are the final hit precipitating the symptoms of Type 1 diabetes [11]. The initiating agent could differ from the accelerating and precipitating agents of the disease. Among them, certain chemical and dietetic factors, plus nitrosamines and virus infections are included $[5,11]$.

In this study the seroconversion to ICA in infected subjects is frequently associated with an increase of $\mathrm{NtAb}$ to EV16, a phenomenon also present in other enterovirus infections $[8,9,10,11,15]$. ICA presence is one of the most important markers of the autoimmune destruction process of beta cells $[4,12,15]$ and it is possible that seroconversion to ICA might be considered a sign of the induction of such process [15].

Interestingly, the presence of NtAb to EV16 in serum was highly associated with the appearance of or increases in ICA titres, with IAA and GADA to a mi- 
nor degree, but not with IA2A concentrations. A similar islet-associated antibody pattern was described in a case report in which maternal infection with echovirus 6 produced Type 1 diabetes in the neonate [33]. In addition, it has been reported [8] that the presence of enterovirus RNA in sera of pre-diabetic subjects was associated with increases in ICA and GADA, but not in IAA or IA 2 concentrations. GADA and IA2A were not found in acute onset of Type 1 diabetes after severe echovirus 9 infection [34]. Recently, the presence of ICA, IAA and IA2A was observed after infection of enterovirus in a child participating in the Finish Diabetes Prediction and Prevention trial [6]. These data suggest that there is heterogeneity of the immune response against beta-cell antigens after echovirus infection. The induction of islet cell associated antibodies seems to occur right after episodes of enterovirus infections. This can take place from weeks to years before diabetes is clinically evident [6].

The presence of high ICA titres in $25.7 \%$ of our subjects could indicate the existence of an important specific immune response against antigenic components of beta cells during infection by echovirus 16 . Accordingly, the high frequencies of IAA and GADA in subjects with high ICA titres in the convalescent stage of the infection might be a reflection of the severity of the beta-cell damage.

The increase in ICA titres does not seem to reflect a general response of autoantibodies since the presence of thyroid microsomal antibodies (TMA) and parietal gastric cells antibodies (PGA) were not detected during the infection.

The mechanisms through which enterovirus infections could contribute to the process leading to Type 1 diabetes are not known. According to our results, echovirus 16 could be involved in an autoimmune induction against beta-cell antigens, due to the fact that the presence of neutralizing antibodies to echovirus 16 was associated with the appearance of or increases in islet-associated antibody concentrations. This suggests that such enterovirus could be capable of inducing the destruction of pancreatic beta cells by releasing self cytoplasmatic antigens, or indirectly generating cytokine production $[7,11,14,15,35,36]$, all of which might trigger Type 1 diabetes of autoimmune origin in subjects with susceptibility genes $[8,10,11,15]$. In addition, molecular mimicry can also be an explanation for this association [7, 11, 14, 20, 35].

It is important to know which enterovirus serotypes are able to induce beta-cell damage. Among such serotypes, CVB4 and CVB5 have most often been connected to the pathogenesis of Type 1 diabetes, although other studies have reported the participation of other enterovirus serotypes, such as coxsackie A and echoviruses (EV4, EV6 and EV9) [11, 14, 16, 17, 18, $19,33,34]$. Echovirus 16 could be another serotype to be included in the list of enteroviruses related to Type 1 diabetes.
According to previous data, the frequency of isolation of echovirus 16 is usually low. Echovirus 16 isolates associated with sporadic cases of aseptic meningitis have not been frequently reported in previous years, probably because of the difficulties in tissue culture propagation [21]. Genotypes of echovirus 16, which are potentially diabetogenic might be "silently" circulating in different world regions. Therefore, those populations with high frequency of Type 1 diabetes might be endemically exposed to this virus.

Our findings show an association of echovirus 16 with the presence of antibodies related to Type 1 diabetes (ICA, IAA and GADA). Echovirus 16 could be involved in initiating the destruction of beta cells in subjects with high genetic risk of developing Type 1 diabetes. In view of that, it might be useful to carry out a large-scale prospective study among children and adolescents exposed to echovirus 16 infection, by exploring the presence of antibodies associated with Type 1 diabetes. It will be important that further epidemiological studies are carried out with special reference to the exposure to echovirus 16 in countries with high incidences of Type 1 diabetes in addition to other studies elucidating how the echovirus 16 infection could contribute to the pathogenesis of Type 1 diabetes.

Acknowledgements. This work was supported in part by a grant from the Ministry of Science, Technology and Environment of Cuba (CITMA). We thank L. Chapel, S. García, M. Hernández, R.E. Palomera and Dr. P. Más for their technical help. We are indebted to Dr. C. Arranz and Dr. J.A. Galvan for the assistance of insulin determination from National Institute of Endocrinology and Biotechnology and Genetic Engineer Center, Havana, as well as to colleagues A. Verrienti and B. Fiore from Endocrinology Service of the University of Rome "La Sapienza”. We are grateful to Dr. S. Conrad, Dr. O. Díaz-Díaz and $\mathrm{T}$. Rode for critical review of the manuscript.

\section{References}

1. Akerblom HK, Knip M (1998) Putative environmental factors in Type 1 diabetes. Diabetes Metab Rev 14:31-67

2. Buzzetti R, Quattrocchi CC, Nistico L (1998) Dissecting the genetics of type 1 diabetes: relevance for familial clustering and differences in incidence. Diabetes Metab Rev 14:111-128

3. Knip M, Akerblom HK (1999) Environmental factors in the pathogenesis of type 1 diabetes mellitus. Exp Clin Endocrinol Diabetes 107 [Suppl 3]:S93-S100

4. Atkinson MA, Eisenbarth GS (2001) Type 1 diabetes: new perspectives on disease pathogenesis and treatment. Lancet 358:221-229

5. Vaarala O, Klemetti P, Juhela S, Simell O, Hyoty H, Ilonen J (2002) Effect of coincident enterovirus infection and cows' milk exposure on immunisation to insulin in early infancy. Diabetologia 45:531-534

6. Hyoty H, Taylor KW (2002) The role of viruses in human diabetes. Diabetologia 45:1353-1361

7. Honeyman MC, Coulson BS, Stone NL et al. (2000) Association between rotavirus infection and pancreatic islet au- 
toimmunity in children at risk of developing type 1 diabetes. Diabetes 49:1319-1324

8. Lonnrot M, Salminen K, Knip M et al. (2000) Enterovirus RNA in serum is a risk factor for beta-cell autoimmunity and clinical type 1 diabetes: a prospective study. Childhood Diabetes in Finland (DiMe) Study Group. J Med Virol 61:214-220

9. Lonnrot M, Korpela K, Knip M et al. (2000) Enterovirus infection as a risk factor for beta-cell autoimmunity in a prospectively observed birth cohort: the Finnish Diabetes Prediction and Prevention Study. Diabetes 49:1314-1318

10. Sadeharju K, Lonnrot M, Kimpimaki T et al. (2001) Enterovirus antibody levels during the first two years of life in prediabetic autoantibody-positive children. Diabetologia 44:818-823

11. Hyoty H, Hiltunen M, Lonnrot M (1998) Enterovirus infections and insulin dependent diabetes mellitus-evidence for causality. Clin Diagn Virol 9:77-84

12. Knip M (1998) Prediction and prevention of type 1 diabetes. Acta Paediatr Suppl 425:54-62

13. Kulmala P, Savola K, Reijonen H et al. (2000) Genetic markers, humoral autoimmunity, and prediction of type 1 diabetes in siblings of affected children. Childhood Diabetes in Finland Study Group. Diabetes 49:48-58

14. Szopa TM, Titchener PA, Portwood ND, Taylor KW (1993) Diabetes mellitus due to viruses-some recent developments. Diabetologia 36:687-695

15. Hiltunen M, Hyoty H, Knip M et al. (1997) Islet cell antibody seroconversion in children is temporally associated with enterovirus infections. Childhood Diabetes in Finland (DiMe) Study Group. J Infect Dis 175:554-560

16. Uriarte A, Cabrera-Rode E, Ventura R, Vargas J (1990) Abnormalities of specific pancreatic immunity in children infected by Echo-4 virus. Rev Cubana Pediatr 62:359-363

17. Uriarte A, Molina G, Cabrera-Rode E, Ventura R, Vargas J, Vera M (1991) Prospective study in children with high risk of type 1 diabetes after infection by Echo- 4 virus (1986-1989). Rev Cubana Endocrinol 2:34-43

18. Cabrera-Rode E (1997) Prevalence of islet cell antibodies (ICA) in diabetes mellitus and other diseases in Cubans. Autoimmunity 26:7-9

19. Diaz-Horta O, Bello M, Cabrera-Rode E et al. (2001) Echovirus 4 and type 1 diabetes mellitus. Autoimmunity 34:275-281

20. Singh B, Delovitch TL (2000) Immune mechanisms that regulate susceptibility to autoimmune type I diabetes. Clin Rev Allergy Immunol 19:247-264

21. Sarmiento L, Mas P, Goyenechea A et al. (2001) First epidemic of echovirus 16 meningitis in Cuba. Emerg Infect Dis 7:887-889

22. Kilpatrick DR, Nottay B, Yang CF et al. (1998) Serotypespecific identification of polioviruses by PCR using primers containing mixed-base or deoxyinosine residues at positions of codon degeneracy. J Clin Microbiol 36:352-357
23. Zoll GJ, Melchers WJ, Kopecka H, Jambroes G, Poel HJ van der, Galama JM (1992) General primer-mediated polymerase chain reaction for detection of enteroviruses: application for diagnostic routine and persistent infections. J Clin Microbiol 30:160-165

24. Yang CF, De L, Yang SJ et al. (1992) Genotype-specific in vitro amplification of sequences of the wild type 3 polioviruses from Mexico and Guatemala. Virus Res 24:277-296

25. Bottazzo GF, Florin-Christensen A, Doniach D (1974) Islet-cell antibodies in diabetes mellitus with autoimmune polyendocrine deficiencies. Lancet 2:1279-1283

26. Pilcher CC, Elliott RB (1990) A sensitive and reproducible method for the assay of human islet cell antibodies. J Immunol Methods 129:111-117

27. Vardi P, Dib SA, Tuttleman M et al. (1987) Competitive insulin autoantibody assay. Prospective evaluation of subjects at high risk for development of type I diabetes mellitus. Diabetes 36:1286-1291

28. Grubin CE, Daniels T, Toivola B et al. (1994) A novel radioligand binding assay to determine diagnostic accuracy of isoform-specific glutamic acid decarboxylase antibodies in childhood IDDM. Diabetologia 37:344-350

29. Verge CF, Stenger D, Bonifacio E et al. (1998) Combined use of autoantibodies (IA-2 autoantibody, GAD autoantibody, insulin autoantibody, cytoplasmic islet cell antibodies) in type 1 diabetes: Combinatorial Islet Autoantibody Workshop. Diabetes 47:1857-1866

30. WHO/EPI/01 (1997) Manual for the virological investigation of polio. Geneva, Switzerland WHO/EPI/GEN/97.01 1997:44-51

31. Hyoty H, Hiltunen M, Knip M et al. (1995) A prospective study of the role of coxsackie B and other enterovirus infections in the pathogenesis of IDDM. Childhood Diabetes in Finland (DiMe) Study Group. Diabetes 44:652-657

32. Dahlquist GG, Ivarsson S, Lindberg B, Forsgren M (1995) Maternal enteroviral infection during pregnancy as a risk factor for childhood IDDM. A population-based case-control study. Diabetes 44:408-413

33. Otonkoski T, Roivainen M, Vaarala O et al. (2000) Neonatal Type I diabetes associated with maternal echovirus 6 infection: a case report. Diabetologia 43:1235-1238

34. Vreugdenhil GR, Schloot NC, Hoorens A et al. (2000) Acute onset of type I diabetes mellitus after severe echovirus 9 infection: putative pathogenic pathways. Clin Infect Dis 31:1025-1031

35. Herrath MG von, Holz A, Homann D, Oldstone MB (1998) Role of viruses in type I diabetes. Semin Immunol 10:87100

36. Seewaldt S, Thomas HE, Ejrnaes M et al. (2000) Virus-induced autoimmune diabetes: most beta-cells die through inflammatory cytokines and not perforin from autoreactive (anti-viral) cytotoxic T-lymphocytes. Diabetes 49:18011809 